JEL Classification: L 52

\title{
ТЕСЕРАКТ КОНКУРЕНТОСПРОМОЖНОСТІ ЯК ГЕНЕРАТОР КОНЦЕПЦІЇ СТАЛОГО РОЗВИТКУ АВТОМОБІЛЬНОЇ ІНДУСТРІЇ
}

\section{Шевченко І.Ю., д-р екон. наук, доцент Харківський національний автомобільно-дорожній університет}

Постановка проблеми. Інтеграція та глобалізація соціальноекономічного простору є невичерпним джерелом як нових можливостей, так i нових загроз національним економікам країн світу. Відкритість кордонів i спільність ринків неминуче призводить до ускладнення конкурентного середовища та загострення конкурентної боротьби, виживання та, тим паче, успіх у якій визначається конкурентоспроможністю продукції, підприємств, підгалузей і галузей національного господарства. В таких умовах найбільш конкурентоспроможними очікувано стають інноваційно активні суб'єкти господарювання, що належать до високотехнологічних індустрій.

Одним із драйверів інноваційного розвитку економік країн світу $\epsilon$ автомобільна індустрія, основою сталого розвитку якої є постійний пошук і впровадження новітніх інженерних рішень. Важливість автомобільної індустрії для соціально-економічного розвитку значною мірою підтверджується статистичними даними European Automobile Manufacturers' Association: наразі автомобілебудівним сектором забезпечується роботою $6,7 \%$ зайнятого населення та створюється 7\% ВВП Європейського Союзу. Вражаючою $є$ інноваційна активність європейських автоконцернів, на які приходяться 29\% всіх витрат на R\&D у Європейському Союзі [1].

«Коронакриза» завдала несподіваного та вкрай потужного удару світовій економіці. Не стала винятком і автомобільна індустрія, де тотальний локдаун лише за II квартал спричинив зниження обсягів виробництва автомобілів практично на 20\% [2]. Ситуація додатково погіршується зменшенням обсягів продажу автомобілів внаслідок відкладення на невизначений термін попиту, особливо на автомобілі економ-класу та середнього класу.

Аналіз останніх досліджень і публікацій. «Криза COVID-19» не мала досі аналогів і суттєво відрізняється від попередніх економічних криз не лише причинами виникнення та характером перебігу, а й невизначеністю часових меж. Наразі вченими все ще не робляться прогнози щодо перспектив подолання глобальних негативних соціально-економічних явищ, спричинених пандемією. Але все частіше у наукових публікаціях звучить полеміка щодо необхідності прийняття нової дійсності та з'являються розробки щодо стабілізації економічної діяльності в умовах карантинних обмежень.

Так, Дж. Вітале, оцінюючи вплив «кризи COVID-19» на автомобільну індустрію та зазначаючи на потенційній довгостроковості цього впливу, 
наголошує на першочерговій необхідності реалізації таких заходів автомобілебудівними підприємствами: визначення пріоритетів і пришвидшення заходів зі зменшення витрат; оптимізація оборотного капіталу та віддання переваги заходам, які забезпечують отримання швидких і відчутних вигід від грошових потоків; перегляд прогнозних припущень із наданням пріоритету сценаріям зменшення, враховуючи поточний рівень ринкової невизначеності; пошук додаткових джерел залучення (запозичення) коштів на випадок виникнення проблем із ліквідністю; забезпечення безпеки та догляду працівників задля збереження робочої сили [3].

Фахівцями Boston Consulting Group було розроблено 4 сценарії розвитку автомобільної індустрії в умовах пандемії, на підставі зіставлення яких було зроблено висновки про необхідність: реалізації комплексного підходу до управління реакцією на «COVID-19 ефекти»; негайного реагування на прояви кризових явищ; складання сценаріїв попиту, прибутків/збитків і грошових потоків; моніторингу й аналізу показників для забезпечення процесу прийняття рішень тощо [4].

International Labour Organization, розуміючи важливість збереження автомобільної індустрії як глобального роботодавця, пропонує дотримуватися 4-ьохстороннього підходу задля нівелювання наслідків пандемії для підгалузі:

1 - захист працівників на робочих місцях;

2 - підтримка підприємств, робочих місць і доходів;

3 - стимулювання економіки та зайнятості;

4 - налагодження соціального діалогу для пошуку рішень [5].

Невирішені складові загальної проблеми. Відновлення та ведення операційної діяльності в умовах пандемії потребує суттєвої трансформації практично всіх систем і підсистем підприємств автомобілебудування. Але вже сьогодні стає цілком зрозумілим, що навіть такі тотальні зміни не дадуть бажаного ефекту без належної державної підтримки, а точніше - без ефективного державно-приватного партнерства.

В Україні актуальність застосування механізму державно-приватного партнерства у протидії негативним наслідкам «коронакризи» для автомобільної індустрії додатково посилюється законодавчим закріпленням автомобільної промисловості як підгалузі машинобудування у якості пріоритетної галузі економіки відповідно до Розпорядження КМУ від 14 серпня 2013 р. № 843-р.

Традиційно реалізація комплексного та системного підходу до вирішення нагальних кризових ситуацій на державному рівні здійснюється через застосування програмно-цільового методу, який полягає у розробленні та реалізації державних цільових програм. При цьому основу будь-якої державної цільової програми складає концепція, яка виступає «каркасом» програмного документу, закріплюючи концепти програми. У сучасних умовах підвищеної нестабільності та невизначеності особливу важливість отримує генерація концепції сталого розвитку автомобільної індустрії у гармонізації до умов конкурентоспроможності автомобілебудівних підприємств. 
У контексті зазначеного в якості інструменту продукування концепції сталого розвитку автомобільної індустрії пропонуємо розроблення тесеракту конкурентоспроможності.

Формулювання цілей статті. Метою статті є розроблення тесеракту конкурентоспроможності як генератору концепції сталого розвитку автомобільної індустрії.

Виклад основного матеріалу дослідження. Для побудови тесеракту (чотиривимірного гіперкуба - аналогу куба в чотиривимірному просторі [6]) конкурентоспроможності як генератору концепції сталого розвитку автомобільної індустрії відповідно до результатів попередніх досліджень автора [7-9], грані внутрішнього куба як елементи конкурентоспроможності підприємств автомобілебудівної підгалузі представимо у вигляді поєднання елементів конкурентоспроможності автомобілебудівної продукції («ціна», «якість», «асортимент» i «сервісне обслуговування») та елементів конкурентного потенціалу автовиробників («виробничий потенціал», «кадровий потенціал», «управлінський потенціал», «інноваційний потенціал», «фінансовий потенціал», «інвестиційний потенціал», «ринковий потенціал» i «стратегічний потенціал»).

Вершини внутрішнього куба як точки перетину його граней є точками виходу (початку) прямих, які з’єднують внутрішній і зовнішній куби тесеракту конкурентоспроможності й уособлюють інструменти забезпечення конкурентоспроможності автомобілебудівних підприємств. Точки закінчення зазначених прямих служать вершинами зовнішнього куба тесеракту конкурентоспроможності та формують концепти (базові елементи концепції сталого розвитку автомобільної індустрії) у вигляді сторін зовнішнього куба.

Рис. 1 наглядно ілюструє розроблений тесеракт конкурентоспроможності як генератор концепції сталого розвитку автомобільної індустрії.

На рис. 1: 1 - ціна; 2 - сервісне обслуговування; 3 - якість; 4 асортимент; 5 - ринковий потенціал; 6 - кадровий потенціал; 7 - виробничий потенціал; 8 - стратегічний потенціал; 9 - фінансовий потенціал; 10 управлінський потенціал; 11 - інноваційний потенціал; 12 - інвестиційний потенціал; 13 - маркетинг; 14 - корпоративна культура; 15 - PLM-система; 16 диференціація; 17 - імідж-менеджмент; 18 - HR-капіталізація; 19 - R\&Dменеджмент; 20 - кооперація; 21 - франчайзингово-дилерська CRM-система; 22 - HR-брендинг; 23 - hi-tech-менеджмент; 24 - кластеризація; 25 - соціальна відповідальність; 26 - інтеграція. 


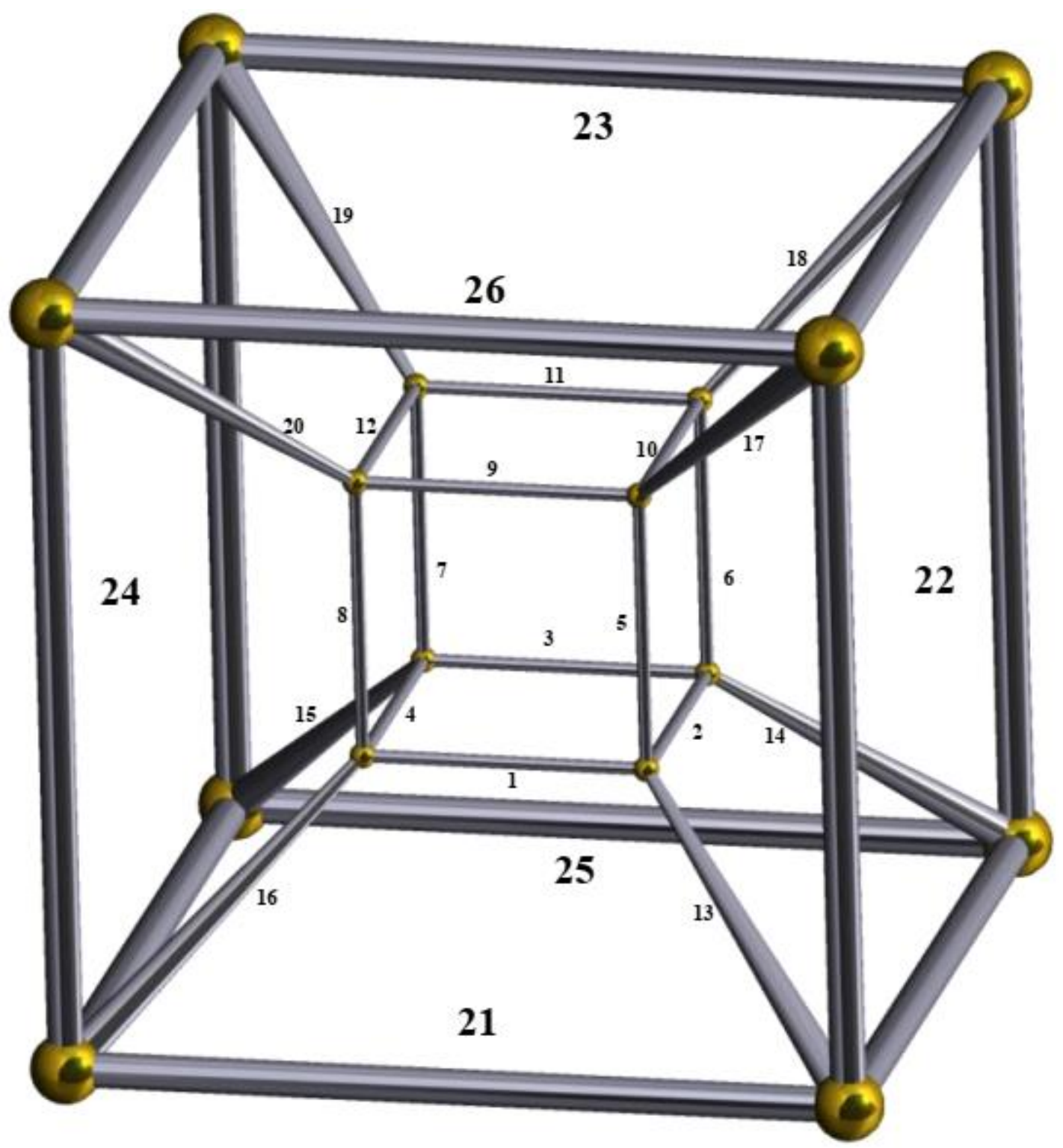

Рис. 1. Тесеракт конкурентоспроможності автомобілебудівних підприсмств і концептів сталого розвитку автомобільної індустрії (авторська розробка)

Висновки 3 проведеного дослідження. 3 рис. 1 бачимо, що концептами державної цільової програми сталого розвитку автомобільної індустрії в сучасних умовах підвищеної нестабільності та невизначеності мають стати:

- франчайзингово-дилерська CRM-система (новітня комплексна система управління відносинами з покупцями автомобілів і бізнес-партнерами);

- HR-брендинг (створення в очах спільноти (зокрема, органів державної влади та місцевого самоврядування/територіальних громад, учасників ринку праці та трудових відносин) стійкого позитивного іміджу автомобілебудівних підприємств як престижних і надійних роботодавців);

- hi-tech-менеджмент (дуальний концепт, який включає: управління «високими технологіями» в автовиробництві як інноваційній індустрії; 
впровадження «високих технологій» в управлінські процеси на підприємствах автомобілебудування);

- кластеризація (використання кращих світових практик формування автомобільних кластерів із залученням представників міжнародних організацій, органів державної влади та місцевого самоврядування/територіальних громад, громадських організацій, профспілок, автомобілебудівних підприємств, підприємств суміжних галузей, закладів вищої освіти, науково-дослідних інститутів і інноваційних центрів);

- соціальна відповідальність (неухильне дотримання норм законодавчих актів і вимог стандартів, екологізація автовиробництва та готової продукції, раціональне використання ресурсів, охорона праці та покращення умов праці, зокрема у напрямку підвищення ергономічності та санітарно-епідеміологічної безпеки робочих місць);

- інтеграція (гармонійне входження до європейської та світової автомобільної індустрії задля забезпечення трансферу технологій).

\section{Перелік посилань}

1. Facts about the automobile industry / European Automobile Manufacturers' Association. URL: https://www.acea.be/automobile-industry/facts-about-the-industry (last accessed 15.09.2020).

2. Interactive map: COVID-19 impact on EU automobile production, first half of 2020 / European Automobile Manufacturers' Association. URL: https://www.acea.be/news/article/interactive-map-covid-19-impact-on-eu-auto-produ ction-first-half-of-2020 (last accessed 15.09.2020).

3. Vitale J. Understanding COVID-19's impact on the automotive sector. 2020. URL: $\quad$ https://www2.deloitte.com/content/dam/Deloitte/global/Documents/AboutDeloitte/COVID-19/gX-COVID-19-Impact-Automotive-Sector.pdf (last accessed 18.09.2020).

4. Collie B., Wachtmeister A. \& Waas A. COVID-19's impact on the automotive industry / Boston Consulting Group. 2020. URL: https://www.bcg.com/ publications/2020/covid-automotive-industry-forecasting-scenarios (last accessed 20.09.2020).

5. COVID-19 and the automotive industry: ILO sectoral brief / International Labour Organization. URL: https:/www.ilo.org/wcmsp5/groups/public/--ed_dialogue/---sector/documents/briefingnote/wcms_741343.pdf (last accessed 22.09.2020).

6. Tesseract / Wikipedia, the free encyclopedia. URL: https://en.wikipedia.org/wiki/Tesseract (last accessed 25.09.2020).

7. Шевченко І. Ю. Історична еволюція та сучасна інтерпретація дефініції сутності категорії «конкурентоспроможність підприємства автомобілебудування». Бізнес Інформ. 2018. № 1. С. 20-27.

8. Шевченко I. Ю. Інтегральна оцінка конкурентоспроможності автомобілебудівних підприємств України. Проблеми $і$ перспективи розвитку підприємництва: Збірник наукових працуь Харківського національного 
автомобільно-дорожнього університету. 2018. № 2(21). С. 211-233. DOI: https://doi.org/10.30977/ ppb.2226-8820.2018.21.0.211.

9. Шевченко I. Ю. Методичні засади оцінювання конкурентоспроможності автомобілебудівних підприємств в контексті формування державної стратегії розвитку автомобілебудування. Вісник Київського національного університету технологій та дизайну. Серія: Економічні науки. 2018. № 4(125). C. 49-61. DOI: https://doi.org/10.30857/ 24130117.2018.4.5.

\section{References}

1. Facts about the automobile industry / European Automobile Manufacturers' Association. URL: https://www.acea.be/automobile-industry/facts-about-the-industry (last accessed 15.09.2020).

2. Interactive map: COVID-19 impact on EU automobile production, first half of 2020 / European Automobile Manufacturers' Association. URL: https://www.acea.be/news/article/interactive-map-covid-19-impact-on-eu-auto-produ ction-first-half-of-2020 (last accessed 15.09.2020).

3. Vitale, J. (2020), Understanding COVID-19's impact on the automotive sector. URL: https://www2.deloitte.com/content/dam/Deloitte/global/Documents/ About-Deloitte/COVID-19/gx-COVID-19-Impact-Automotive-Sector.pdf (last accessed 18.09.2020).

4. Collie, B., Wachtmeister, A. \& Waas, A. (2020), COVID-19's impact on the automotive industry / Boston Consulting Group. URL: https://www.bcg.com/ publications/2020/covid-automotive-industry-forecasting-scenarios (last accessed 20.09.2020).

5. COVID-19 and the automotive industry: ILO sectoral brief / International Labour Organization. URL: https://www.ilo.org/wcmsp5/groups/public/--ed_dialogue/---sector/documents/briefingnote/wcms_741343.pdf (last accessed 22.09.2020).

6. Tesseract / Wikipedia, the free encyclopedia. URL: https://en.wikipedia.org/wiki/Tesseract (last accessed 25.09.2020).

7. Shevchenko, I. Yu. (2018), Historical evolution and current interpretation of the definition of essence of the category of "competitiveness of enterprise of the automobile industry" [Istorychna evoliutsiia ta suchasna interpretatsiia definitsii sutnosti katehorii "konkurentospromozhnist pidpryiemstva avtomobilebuduvannia"], Business Inform, No 1, P. 20-27.

8. Shevchenko, I. Yu. (2018), Integral assessment of the competitiveness of the automotive enterprises of Ukraine [Intehralna otsinka konkurentospromozhnosti avtomobilebudivnykh pidpryiemstv Ukrainy], Problems and perspectives of entrepreneurship development, No 2(21), P. 211-233. DOI: https://doi.org/10.30977/ ppb.2226-8820.2018.21.0.211

9. Shevchenko, I. Yu. (2018), Methodological framework for assessing the competitiveness of automotive companies in the context of building the government strategy for automotive industry development [Metodychni zasady otsiniuvannia 
konkurentospromozhnosti avtomobilebudivnykh pidpryiemstv $\mathrm{u}$ konteksti formuvannia derzhavnoi stratehii rozvytku avtomobilebuduvannia], Bulletin of the Kyiv National University of Technologies and Design. Series: Economic sciences, No 4(125), P. 49-61. DOI: https://doi.org/10.30857/ 2413-0117.2018.4.5.

\section{РЕФЕРАТИ РЕФЕРАТЫ ABSTRACTS}

\section{УДК 338.242; JEL Classification: L 52}

ШевчеНКО І.Ю. ТЕСЕРАКТ КОНКУРЕНТОСПРОМОЖНОСТІ ЯК ГЕНЕРАТОР КОНЦЕПЦІї СТАЛОГО РОЗВИТКУ АВТОМОБІЛЬНОӦ ІНДУСТРІї

Mema: розроблення тесеракту конкурентоспроможності як генератору концепції сталого розвитку автомобільної індустрії. Методика дослідження: метод аналізу та синтезу, системний підхід, метод узагальнення, графічний метод. Результати: розроблено тесеракт конкурентоспроможності як генератор концепції сталого розвитку автомобільної індустрії. Грані внутрішнього куба тесеракту як елементи конкурентоспроможності підприємств автомобілебудівної підгалузі представлено у вигляді поєднання елементів конкурентоспроможності автомобілебудівної продукції («ціна», «якість», «асортимент» i «сервісне обслуговування») та елементів конкурентного потенціалу автовиробників («виробничий потенціал», «кадровий потенціал», «управлінський потенціал», «інноваційний потенціал», «фінансовий потенціал», «інвестиційний потенціал», «ринковий потенціал» і «стратегічний потенціал»). Вершини внутрішнього куба тесеракту як точки перетину його граней є точками виходу (початку) прямих, які з'єднують внутрішній і зовнішній куби тесеракту й уособлюють інструменти забезпечення конкурентоспроможності автомобілебудівних підприємств. Точки закінчення зазначених прямих служать вершинами зовнішнього куба тесеракту конкурентоспроможності та формують концепти (базові елементи концепції сталого розвитку автомобільної індустрії) у вигляді сторін зовнішнього куба. Наукова новизна: розроблений тесеракт забезпечує генерацію концепції сталого розвитку автомобільної індустрії у гармонізації 3 умовами конкурентоспроможності автомобілебудівних підприємств. Практична значущість: практичне застосування тесеракту конкурентоспроможності дозволило згенерувати сучасні концепти сталого розвитку автомобільної індустрії: франчайзингово-дилерська CRM-система; HR-брендинг; hi-techменеджмент; кластеризація; соціальна відповідальність; інтеграція.

Ключові слова: автомобільна індустрія; конкурентоспроможність; концепція; тесеракт; сталий розвиток; автомобілебудівне підприємство. 


\section{УДК 338.242; JEL Classification: L 52}

\section{ШевчеНКО И.Ю. ТЕССЕРАКТ КОНКУРЕНТОСПОСОБНОСТИ}

КАК ГЕНЕРАТОР КОНЦЕПЦИИ УСТОЙЧИВОГО РАЗВИТИЯ АВТОМОБИЛЬНОЙ ИНДУСТРИИ

Цель: разработка тессеракта конкурентоспособности как генератора концепции устойчивого развития автомобильной индустрии. Методика исследования: метод анализа и синтеза, системный подход, метод обобщения, графический метод. Pезультаты: разработано тессеракт конкурентоспособности как генератор концепции устойчивого развития автомобильной индустрии. Грани внутреннего куба тессеракта как элементы конкурентоспособности предприятий автомобилестроительной подотрасли представлено в виде сочетания элементов конкурентоспособности автомобилестроительной продукции («цена», «качество», «ассортимент» и «сервисное обслуживание») и элементов конкурентного потенциала автопроизводителей («производственный потенциал», «кадровый потенциал», «управленческий потенциал», «инновационный потенциал», «финансовый потенциал», «инвестиционный потенциал», «рыночный потенциал» и «стратегический потенциал»). Вершины внутреннего куба тессеракта как точки пересечения его граней являются точками выхода (начала) прямых, которые соединяют внутренний и внешний кубы тессеракта и олицетворяют инструменты обеспечения конкурентоспособности автомобилестроительных предприятий. Точки окончания указанных прямых служат вершинами внешнего куба тессеракта конкурентоспособности и формируют концепты (базовые элементы концепции устойчивого развития автомобильной индустрии) в виде сторон внешнего куба. Научная новизна: разработанный тессеракт обеспечивает генерацию концепции устойчивого развития автомобильной индустрии в гармонизации с условиями конкурентоспособности автомобилестроительных предприятий. Практическая значимость: практическое применение тессеракта конкурентоспособности позволило сгенерировать современные концепты устойчивого развития автомобильной индустрии: франчайзингово-дилерская CRM-система; HR-брендинг; hi-techменеджмент; кластеризация; социальная ответственность; интеграция.

Ключевые слова: автомобильная индустрия; конкурентоспособность; концепция; тессеракт; устойчивое развитие; автомобилестроительное предприятие.

\section{UDC 338.242; JEL Classification: L 52}

Shevchenko I.Yu. TESERACT OF COMPETITIVENESS AS A GENERATOR OF THE CONCEPT OF SUSTAINABLE DEVELOPMENT OF THE AUTOMOTIVE INDUSTRY

Purpose: development of the tesseract of competitiveness as a generator of the concept of sustainable development of the automotive industry. Methodology of research: method of analysis and synthesis, system approach, generalization method, 
graphic method. Findings: the tesseract of competitiveness as a generator of the concept of sustainable development of the automotive industry is developed. The facets of the internal cube of tesseract as elements of competitiveness of automotive industry are presented as a combination of elements of competitiveness of automotive products ("price", "quality", "range" and "service") and elements of competitive potential of automakers ("production potential", "human resources potential", "managerial potential", "innovation potential", "financial potential", "investment potential", "market potential" and "strategic potential"). The vertices of the inner cube of the tesseract as the points of intersection of its faces are the points of the beginning of the lines that connect the inner and outer cubes of the tesseract and represent the tools for ensuring the competitiveness of the automotive enterprises. The points of end of these lines serve as the vertices of the outer cube of tesseract of competitiveness and form concepts (basic elements of the concept of sustainable development of the automotive industry) as the sides of the outer cube. Originality: the developed tesseract provides generation of concepts of sustainable development of the automotive industry in harmonization with conditions of competitiveness of automotive enterprises. Practical value: practical application of the tesseract of competitiveness allowed to generate the modern concepts of sustainable development of the automotive industry: franchise-dealer CRM-system; HR branding; hi-tech management; clustering; social responsibility; integration.

Key words: automotive industry; competitiveness; concept; tesseract; sustainable development; automotive enterprise.

\section{Відомості про авторів / Сведения об авторах / About the Authors}

Шевченко Інна Юріївна - доктор економічних наук, доцент, Харківський національний автомобільно-дорожній університет, завідувач кафедри економіки i підприємництва, м. Харків, Україна; e-mail: shevchenko.khnadu@gmail.com; ORCID ID：0000-0003-0758-9244. Моб. (066) 187-28-30.

Шевченко Инна Юрьевна - доктор экономических наук, доцент, Харьковский национальный автомобильно-дорожный университет, заведующий кафедрой экономики и предпринимательства, г. Харьков, Украина.

Shevchenko Inna - Doctor of Economics, Associate Professor, Kharkiv National Automobile and Highway University, Head of the Department of Economics and Entrepreneurship, Kharkiv, Ukraine. 